\title{
Antibacterial Activity of Native Bacillus thuringiensis Strains from Fernandez Canyon State Park, Mexico
}

\author{
Lopez de la Cruz $\mathrm{D}^{1,5}$, Valencia-Castro $\mathrm{CM}^{1,2}$, Hernández-Terán $\mathrm{F}^{1,2}$, Barboza-Corona $\mathrm{JE}^{3,4}$ and de la Fuente-Salcido $\mathrm{NM}^{1,2^{*}}$ \\ ${ }^{1}$ Graduate program in Biochemical Engineering, Faculty of Biological Sciences, Autonomous University of Coahuila, México \\ ${ }^{2}$ Bioprospecting and Bioprocesses Department, Faculty of Biological Sciences, Autonomous University of Coahuila, México \\ ${ }^{3}$ Graduate program in Biosciences, Division of Life Sciences, University of Guanajuato Campus Irapuato-Salamanca, México \\ ${ }^{4}$ Department of Food, Division of Life Sciences, University of Guanajuato Campus Irapuato-Salamanca, México \\ ${ }^{5}$ Agricultural Technological Baccalaureate Center No.206, Matamoros, Coahuila, México
}

*Corresponding author: Norma M. de la Fuente-Salcido, Graduate program in Biochemical Engineering, Bioprospecting and Bioprocesses Department, Autonomous University of Coahuila, Faculty of Biological Sciences, Torreón, Coahuila, 27275, México, Tel: +52-871-757-1785; E-mail: normapbr322@gmail.com

Received date: February 21, 2018; Accepted date March 14, 2018; Published date: March 15, 2018

Copyright: (c) 2018 Lopez de la Cruz L, et al. This is an open-access article distributed under the terms of the Creative Commons Attribution License, which permits unrestricted use, distribution, and reproduction in any medium, provided the original author and source are credited.

\begin{abstract}
Bacillus thuringiensis is a microbial insecticide whose presence in the Fernandez Canyon State Park, a protected natural area in the north of Mexico, has not been reported. The objective of this work was to isolate Bacillus thuringiensis strains isolated from the Fernandez Canyon State Park with the capacity to synthesize antimicrobial peptides (bacteriocins). We showed the isolation and characterization of two native strains of Bacillus thuringiensis (CF13 and CF42) collected from soils of the protected area. Bacteria were identified based on its capacity to synthesize spherical crystals and by sequencing of the flagellin gene. Both strains produced bacteriocins with bactericial/bacteriolytic activity against Bacillus cereus, with molecular mass of $10 \mathrm{kDa}$ and $15 \mathrm{kDa}$, susceptible to proteolytic treatment, thermotolerants and with activity to ten Gram-positive and eight Gram-negative bacteria that might affect human and animal health. The importance of this work is that it is reported for the first time the isolation and characterization of bacteriocinogenic strains of Bacillus thuringiensis native from the Fernandez Canyon State Park, a protected natural area in Mexico.
\end{abstract}

Keywords: Bacillus thuringiensis, Bacteriocins; Antibacterial activity; Fernandez canyon; Mexico

\section{Introduction}

Bacillus thuringiensis is the most important microbial bioinsecticide used worldwide, and its activity is due to the production of intracellular crystals formed mainly by $C r y$ and $C y t$ proteins $[1,2]$. Additionally, Bacillus thuringiensis produce different metabolites with biotechnological potential value, including, bacteriocins, chitinases, vegetative proteins (VIP), enhancing like proteins, SIP toxins, proteins related to cholesterol-dependent cytolysins, beta exotoxins and lipases, among others [2-4]. Currently, most studies related to the isolation of Bacillus thuringiensis strains have been focused on entomotoxicity, crystal morphology, and the Cry genes composition present in the bacterial isolates $[5,6]$. In comparison, less studies on bacteriocins have been reported, but they are of significant interest because their inhibitory effect against bacteria of importance in human and animal health $[3,7]$.

Although there has been reports on the isolation and characterization of Mexican Bacillus thuringiensis strains from the states of Baja California Norte, Michoacán, Nayarit and Guanajuato, México [6,7] among others, few studies have focused on the capacity of these microbes to produce bacteriocins [8]. Bacillus thuringiensis is a cosmopolitan bacterium, but to our knowledge there is not report about the isolation of this microorganism in the Fernandez Canyon State Park ("Parque Estatal Cañón de Fernandez"), a protected natural area located in norther of México between the states of Coahuila and
Durango, in a region known as "Comarca Lagunera" [9]. The objective of this study was to select Bacillus thuringiensis strains from the Fernandez Canyon State Park based on their capacity to produce bacteriocins, with the purpose of extending the knowledge of these metabolites synthesized by this bacterium.

\section{Material and Methods}

\section{Bacterial strains}

We used a collection of Bacillus sp (158 strains) held at "Laboratorio de Bioprospección y Bioprocesos" of the "Universidad Autónoma de Coahuila", obtained by sampling the flood plain soil from Fernandez Canyon State Park. Subsequently using phase contrast microscopy (Imager A1, Carl Zeiss, Jena, Germany), we selected isolates that produced intracellular crystals, which were classified as putative Bacillus thuringiensis strains.

\section{Growth of strains and metabolite production}

Selected bacteria were grown in synchronous cultures using Tryptic soy broth (TSB) at $30 \pm 2^{\circ} \mathrm{C}, 180 \mathrm{rpm}$ for $120 \mathrm{hr}$. Duplicate aliquots were taken at different times. The first aliquot was used for monitoring the cellular growth $(600 \mathrm{~nm})$. The second was centrifuged at $9000 \mathrm{xg}$, 10 minutes, and the cell-free supernatants were obtained by filtration using a syringe filter with $0.45 \mu \mathrm{M}$ pore size (Merck Millipore, Darmstadt, Germany). Cell-free supernatants were used for assaying the antibacterial activity. The antibacterial activity was determined by the well-diffusion method against Bacillus cereus 183 used as indicator 
Citation: Lopez de la Cruz D, Valencia-Castro CM, Hernández-Terán F, Barboza-Corona JE, de la Fuente-Salcido NM (2018) Antibacterial Activity of Native Bacillus thuringiensis Strains from Fernandez Canyon State Park, Mexico. J Antimicrob Agents 4: 166. doi: $10.4172 / 2472-1212.1000166$

Page 2 of 5

bacterium [8]. Two isolates, CF13 and CF42, with the highest antibacterial activity were selected for further studies.

\section{Molecular identification by $16 \mathrm{~S}$ rDNA and flagellin gene sequence}

To confirm the identity of CF13 and CF42, $1.5 \mathrm{~mL}$ of bacterial cultures were grown during $18 \mathrm{hr}$ at $200 \mathrm{rpm}$, centrifuged at $9000 \mathrm{~g}$ for $5 \mathrm{~min}$, the pellets were resuspended in $200 \mu \mathrm{L}$ of distilled water and boiled during $15 \mathrm{~min}$. We amplified the $16 \mathrm{~S}$ rDNA sequence and the hag gene by polymerase chain reactions, using the oligonucleotides UBF (F: 5'-AGAGTTTGATCCTGGCTGAG-3') and 1492 (R: 5'GGTTACCTTGTTACGACTT-3') [10], and BtFlaA5 (F: 5'ATGAGCAATTCTATGGACCG-3', R: BtFlaA6 5'TTTCAGACATTTCTTTCGCC-3'), respectively. The 16S rDNA sequence was amplified using conditions previously described [10], and the hag gene as follows: $5 \mathrm{~min}$ at $95^{\circ} \mathrm{C} ; 30$ cycles of $1 \mathrm{~min}$ at $95^{\circ} \mathrm{C}, 1$ min at $48^{\circ} \mathrm{C}$ (or $58^{\circ} \mathrm{C}$ ) and $2 \mathrm{~min}$ (or $4 \mathrm{~min}$ ) at $72^{\circ} \mathrm{C}$, with a final extension of $7 \mathrm{~min}$ at $72^{\circ} \mathrm{C}$ [11], in a C1000 Touch TM thermocycler (Bio-Rad, Hercules, CA, USA). Amplicons were purified from agarose gels using the QIAprep Spin Miniprep Kit (250) (Qiagen) and sequenced at the National Laboratory of Genomics for Biodiversity (Langebio, at CINVESTAV-Irapuato, México). Sequences were compared with those reported in the GenBank data and analyzed by Basic Local Alignment Tool (BLAST) of the National Center for Biotechnology (NCBI)

\section{Bacteriocin production}

Batch fermentation under the same conditions described previously was carried out. Cells were harvested at the time where the maximum production of bacteriocin were detected. Cultures were centrifuged at $9000 \mathrm{Xg}$ during $15 \mathrm{~min}$ at $4^{\times} \mathrm{C}$, supernatants were collected and proteins were concentrated with ammonium sulfate at different saturation values $(20,40,60,80$ and $100 \%)$. Samples were incubated at least $1 \mathrm{hr}$, at $4^{\circ} \mathrm{C}$ [12], centrifuged $9000 \mathrm{\chi g}$ and crude samples containing bacteriocins were resuspended in phosphate buffer $100 \mathrm{mM}$ $\mathrm{pH}$ 6.8. Samples were dialyzed overnight against the same buffer using a mini dialysis kit with membrane of $3.5 \mathrm{kDa}$ cut off (Amersham Bioscience).

\section{Determination of antibacterial activity}

The antibacterial activity was determined against Gram-positive and Gram-negative bacteria by the well-diffusion method [8]. A clear halo around $\geq 1 \mathrm{~mm}$ beyond the well-diameter indicates that compounds inside the well, present in the crude extracts, have inhibitory effect against indicator bacterium. One arbitrary unit of inhibitory activity was defined as equal to $1 \mathrm{~mm}^{2}$ of the zone of inhibition of growth of the indicator bacterium. Each point of activity was repeated in triplicate and the average was recorded.

\section{Effect of physiochemical parameters on antibacterial activity}

Bacteriocin activity were evaluated in a $\mathrm{pH}$ range of 5 to 9 using a buffer containing citric acid, glycine, sodium phosphate, MES [2 (nmorpholino) ethane sulfonic acid], Trizma base [Tris (hidroxymethyl) aminoethane] with a final concentration of $100 \mathrm{mM}$. Then $75 \mu \mathrm{L}$ of buffer were mixed with $25 \mu \mathrm{L}$ of crude bacteriocin, and incubated aseptically $1 \mathrm{hr}$ at $28^{\circ} \mathrm{C}$. Antibacterial activity also was evaluated at different temperatures $\left(50,60,70,80,90\right.$ and $\left.121^{\circ} \mathrm{C}\right)$ for 20 minutes.
The well-diffusion assay was carried out as previously was described to determine the activity.

\section{Effect of proteolytic enzymes on antibacterial activity}

To evaluate whether components with antibacterial activity were of proteinaceous nature, crude samples were treated with protease, trypsin and chymotrypsin (Sigma-Aldrich, St. Louis, MO, USA) and proteinase K (New England Biolabs, Ipswich, MA, USA). Samples of 90 $\mu \mathrm{L}$ were incubating with $10 \mu \mathrm{L}$ of enzyme $(1 \mathrm{mg} / \mathrm{mL})$ in the appropriate buffer at $37^{\circ} \mathrm{C}$ for $2 \mathrm{hr}$ or at $42^{\circ} \mathrm{C}$ with protease $\mathrm{K}$. The antibacterial activity of all the reactions was determined by the welldiffusion assay against Bacillus cereus as indicator bacterium [8].

\section{Effect of bacteriocins to inhibit another bacterial growth}

To determine the effect of bacteriocins on a culture of Bacillus cereus 183, the indicator bacterium, $100 \mathrm{~mL}$ of fresh bacterial cultures with $\sim 1 \times 10^{9}$ cells $/ \mathrm{mL}$ was inoculated with $\sim 3000 \mathrm{U}$ of bacteriocins in the middle of logarithmic-phase $(\sim 3 \mathrm{hr})$, and the effect on bacterial viability of Bacillus cereus was evaluated at different intervals of time (0-60 minutes) using a micro-plate reader Synergy HTX (Biotek). Cultures of Bacillus cereus 183 no supplemented with bacteriocins were used as negative controls [13].

\section{Antibacterial activity determined by gel-overlay assay}

To estimate the molecular mass of putative bacteriocins, crudes samples were treated with Laemmli's buffer without mercaptoethanol and then loaded in two sodium dodecyl sulfate (SDS)-polyacrylamide (16\%) gels for electrophoresis (SDS-PAGE). One gel was stained Coomassie blue, and the second gel was used to determine the antibacterial activity in a gel-overlay assay as previously indicated [8].

\section{Results}

\section{Crystal production}

From 158 bacterial strains isolated from Fernandez Canyon State Park belonging to "Laboratorio de Bioprospección y Bioprocesos" of the "Universidad Autónoma de Coahuila", 44\% have antibacterial activity, $13 \%$ were spore-forming and $6 \%$ produce intracellular crystal. From crystalliferous strains, CF13 and CF42 were selected because they had the highest antibacterial activity. Both strains are sporogenic and produce spherical crystals (Figure 1A). We determined the growth curve (data not shown) of CF42 and CF13, and observed that the highest bacteriocins production of these isolates occurred in the exponential $(12 \mathrm{hr})$ and in the beginning stationary $(24 \mathrm{hr})$ phases of growth, respectively (Figure 1B) and the high activity concentration was detected at $80 \%$ of ammonium sulfate saturation in both strains. Similar behavior has been reported for other bacteriocins produced by Mexican strains whose maximum activity was observed at the start or at the end of the stationary stage $[8,14]$.

\section{Molecular identification by $16 \mathrm{~S}$ rDNA and flagellin gene sequence}

Based on both $16 \mathrm{~S}$ rDNA and hag sequences, these strains were identified as Bacillus thuringiensis subsp. kenyae (identities 100\%). The hag gene encodes the flagellin, which is a protein responsible for eliciting the immunological reaction in $\mathrm{H}$ serotyping, allowing the identification and assignation of the subspecies [15]. 
Citation: Lopez de la Cruz D, Valencia-Castro CM, Hernández-Terán F, Barboza-Corona JE, de la Fuente-Salcido NM (2018) Antibacterial Activity of Native Bacillus thuringiensis Strains from Fernandez Canyon State Park, Mexico. J Antimicrob Agents 4: 166. doi: $10.4172 / 2472-1212.1000166$

Page 3 of 5

\section{Determination of antibacterial activity}

Both strains also showed a broad spectrum of activity, with inhibitory effects against ten Gram-positive and eight Gram-negative bacteria. The highest activity was observed against four Gram-positive (i.e. Streptococcus uberis, Enterococcus faecalis, Bacillus cereus 183, Equi subsp. zooepidermicus), and two negative bacteria (Pseudomonas aeuruginosa and Enterobacter cloacae). Unfortunately, neither CF13 nor CF42 showed inhibitory effect against Brucella sp., genus of importance in human health (Table 1).

\begin{tabular}{|c|c|c|c|}
\hline Type & Indicator bacteria & CF13 & CF42 \\
\hline \multirow{10}{*}{$\begin{array}{l}\text { Gram- } \\
\text { positive }\end{array}$} & Bacillus cereus 183 & $255^{d}$ & $255^{d}$ \\
\hline & Bacillus subtilis & $118 \pm 12^{b}$ & $188 \pm 12 b$ \\
\hline & Listeria inoccua & $198 \pm 0^{c}$ & $198 \pm 0^{c}$ \\
\hline & $\begin{array}{l}\text { Listeria monocytognes } \\
\text { Scott }\end{array}$ & $190 \pm 15^{c}$ & $198 \pm 0^{c}$ \\
\hline & Enterococcus faecium & $118 \pm 12^{b}$ & $118 \pm 12^{b}$ \\
\hline & Enterococcus faecalis & $275 \pm 17^{e}$ & $275 \pm 17^{e}$ \\
\hline & Staphylococcus lentus & $35 \pm 0^{\mathrm{a}}$ & $35 \pm 0^{a}$ \\
\hline & Staphylococcus aureus & $118 \pm 12$ & $245 \pm 16^{d}$ \\
\hline & Streptococcus uberis & $285 \pm 0^{e}$ & $285 \pm 0^{e}$ \\
\hline & $\begin{array}{l}\text { Str. equi } \quad \text { subsp. } \\
\text { zooepidemicus }\end{array}$ & $245 \pm 16^{d}$ & $245 \pm 16^{d}$ \\
\hline \multirow{8}{*}{$\begin{array}{l}\text { Gram- } \\
\text { negative }\end{array}$} & Enterobacter cloacae & $217 \pm 16^{e}$ & $207 \pm 16^{e}$ \\
\hline & Pseudomona aeruginosa & $318 \pm 0^{f}$ & $318 \pm 0^{f}$ \\
\hline & Salmonella sp & $98 \pm 11^{b}$ & $91 \pm 11^{b}$ \\
\hline & Salmonella typhimurium & $172 \pm 0^{c}$ & $181 \pm 15^{d}$ \\
\hline & Brucella sp & $0 \pm 0^{a}$ & $0 \pm 0^{a}$ \\
\hline & Shigella sonnei & $111 \pm 12^{b}$ & $91 \pm 11^{b}$ \\
\hline & Shigella flexneri & $198 \pm 0^{d}$ & $172 \pm 0^{d}$ \\
\hline & Klebsiella pneumoniae & $181 \pm 15^{c}$ & $148 \pm 0^{c}$ \\
\hline
\end{tabular}

Table 1: Inhibitory activity (U) of partially purified bacteriocins of Bacillus thuringiensis CF13 and CF42 determined by the well-diffusion method. Values with different letters in the same column are significantly different as determined by Tukey's multiple range test $(\mathrm{P}<$ $0.05)$.

\section{Effect of physiochemical parameters on antibacterial activity}

We tested the effect of $\mathrm{pH}$ and temperature on the antibacterial activity. Bacteriocins produced by strains CF13 and CF42 showed activity in a $\mathrm{pH}$ range of 5 to $9 \mathrm{pH}$ range with a maximum activity at pH 6.5 (Figure 1C); they were thermoresistant as they retained activity even at temperature of $121^{\circ} \mathrm{C}$, maintaining a residual activity of $45 \%$ (data not show). Other bacteriocins, such as kenyacin 404, entomocin 420 and tolworthcin 524, are thermoresistants [8]. The proteinaceous nature of bacteriocins was confirmed by their susceptibility to proteolytic enzymes.

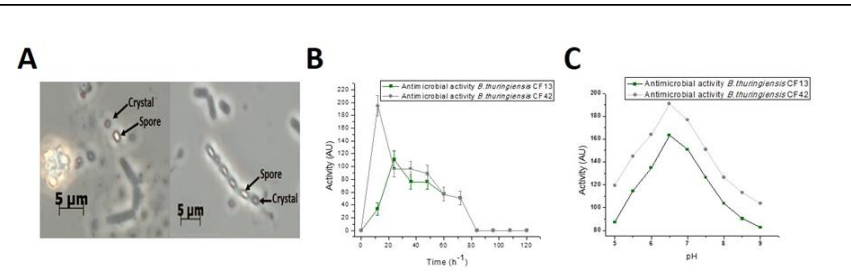

Figure 1: Identification of Bacillus thuringiensis strains by phase contrast microscopy and their antibacterial activity using Bacillus cereus 183 used as indicator strain. (A) Sporulated samples of Bacillus thuringiensis CF13 (left) and CF42 (right). Crystals and spores are indicated by arrows (B) Antibacterial activities at growth different times and (C) Effect of $\mathrm{pH}$ on the antibacterial activities of CF13 and CF42.

\section{Effect of bacteriocins to inhibit another bacterial growth}

When bacteriocins were tested against Bacillus cereus 183 (the indicator strain), a marked bacteriolytic effect was detected by plotting the cell growth records of the indicator strain with and without the bacteriocins synthesized by CF13 and CF42 strains (Figures 2A and 2B). Similar results have been observed with other bacteriocins of Bacillus thuringiensis [13].

\section{Antibacterial activity determined by gel-overlay assay}

It was found that both strains CF13 and CF42 produce two proteins of $\sim 10 \mathrm{kDa}$ and $15 \mathrm{kDa}$ with inhibitory activity against Bacillus cereus used in this study as indicator bacterium (Figure 2C).

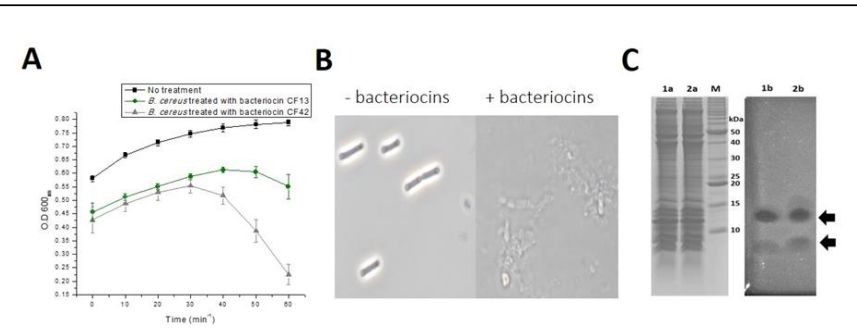

Figure 2: Characterization of bacteriocins using B cereus 183 as indicator strain. (A) Effect of partially purified bacteriocins on the growth of B. cereus 183. (B) Lytic effect of bacteriocins of CF13 strain; right panel, B. cereus treated with bacteriocins of Bacillus thuringiensis $\mathrm{CF} 13$; left panel, negative control, cells non-treated with bacteriocins. (C) Direct detection of the antibacterial activity. Left, SDS-PAGE; right, gel-overlay assay using Bacillus cereus as indicator bacterium. Lanes $1 \mathrm{a}$ and $1 \mathrm{~b}$, crude extracts of CF13; lanes $2 \mathrm{a}$ and $2 \mathrm{~b}$, crude extracts of CF42. Arrows indicate the relative position $(\sim 15 \mathrm{kDa}$ and $10 \mathrm{kDa})$ of the growth inhibition zones observed after overnight incubation at $28^{\circ} \mathrm{C}$.

\section{Discussion}

Currently we do not have information about the isolation of Bacillus thuringiensis strains in the Fernandez Canyon State Park at México. Here, we selected two Bacillus thuringiensis strains from soil samples bases on its antibacterial activity. Our purpose was to expand the 
Citation: Lopez de la Cruz D, Valencia-Castro CM, Hernández-Terán F, Barboza-Corona JE, de la Fuente-Salcido NM (2018) Antibacterial Activity of Native Bacillus thuringiensis Strains from Fernandez Canyon State Park, Mexico. J Antimicrob Agents 4: 166. doi: $10.4172 / 2472-1212.1000166$

Page 4 of 5

knowledge of bacteria present in a protected area in Mexico and to find metabolites that might be novel and with potential applied value.

It has been reported that bacteria produce antimicrobial peptides or bacteriocins to compete and communicate with others microorganisms by quorum sensing [16]. To date it has been reported approximately twenty-two bacteriocins of Bacillus thuringiensis, but it is unknown what percent represent the same bacteriocins $[17,18]$ as it has only been reported the whole amino acid sequence of four bacteriocins produced by this bacterium, i.e. two-component Bacteriocins Thuricin CD, Thusin, Thurincin $\mathrm{H}$ and cold-shock bacteriocin protein, which have molecular masses between 3 and 7 $\mathrm{kDa}$ [19-22]. Interesting, by SDS-PAGE we found that both Bacillus thuringiensis strains produced two proteins of $\sim 10 \mathrm{kDa}$ and $15 \mathrm{kDa}$ with inhibitory activity against Bacillus cereus. Previously we showed that a native strain of Bacillus thuringiensis synthesized a protein 10 $\mathrm{kDa}$ with inhibitory effect against Bacillus cereus, identified as Thurincin $\mathrm{H}[8,14]$. It is possible that protein of $\sim 15 \mathrm{kDa}$ represent a novel bacteriocin, but further experiments will be required to demonstrate or discard it. The highest production of bacteriocins from Bacillus thuringiensis $\mathrm{CF} 42$ and $\mathrm{CF} 13$ were observed in the logarithmic or in the stationary period, respectively [8], which suggest that they might be different. Also both strains showed a broad spectrum of activity with inhibitory effect to Gram-positive and Gramnegative bacteria of importance in human and animal health. The highest activity was observed against four Gram-positive bacteria such as Bacillus cereus 183, Str. Equi subsp. zooepidermicus, Streptococcus uberis, Enterococcus faecalis, and two negative bacterium, i.e. Pseudomonas aeuruginosa and Enterobacter cloacae. Neither CF13 nor CF42 showed inhibitory effect against Brucella sp, microorganism of importance in human health. When bacteriocins were tested against Bacillus cereus, we observed a bacteriolytic effect, likewise to the observed with other bacteriocins of Bacillus thuringiensis such as kurstacin 287, entomocin 110, thuricin 7 and thuricin CD [13,23-26].

\section{Conclusion}

It was isolated by first time; strains of Bacillus thuringiensis from a protected area in México called the Fernandez Canyon State Park, and demonstrate that they synthesize bacteriocins with potential applied value. It will be necessary to clone the genes responsible for their synthesis, to know the amino acid sequences and confirm (or discard) the novelty compared with other bacteriocins of Bacillus thuringiensis isolated from different sources.

\section{Conflict of interest}

The authors declare that there is no conflict of interest.

\section{Acknowledgements}

This research was supported by Grant SEP-CONACyT (258220) México to JEBC. Daniel López de la Cruz is a graduate student supported by CONACyT, México. We thank Dr. Rubén SalcedoHernández from "University of Guanajuato", México, and Dr. Dennis K. Bideshi from California Baptist University, USA, for the critical reading of the manuscript.

\section{References}

1. Bravo A, Likitvivatanavong S, Gill S, Soberón S (2011) Bacillus thuringiensis: A story of a successful bioinsecticide. Insect Biochem Mol Biol 41: 423-431.

2. Palma L, Muñoz D, Berry C, Murillo J, Caballero P (2014) Bacillus thuringiensis toxins: An overview of their biocidal activity. Toxins 6: 3296-3325.

3. Fuente-Salcido NM, Vázquez LEC, Pérez APG, Pérez UEB, Bideshi DK, et al. (2016) The endochitinase ChiA Btt of Bacillus thuringiensis subsp. Tenebrionis DSM-2803 and its potential use to control the phytopathogen Colletotrichum gloeosporioides. Microbiol Open 5: 819-829.

4. Chávez AJG, Ortega EAM, Posadas MV, Galván MFL, Salcido NMF, et al. (2016) Potential use of Bacillus thuringiensis bacteriocins to control antibiotic-resistant bacteria associated with mastitis in dairy goats. Folia Microbiol 61: 11-19.

5. Rabha M, Sharma S, Acharjee S, Sarmah BK (2017) Isolation and characterization of Bacillus thuringiensis strains native to Assam soil of North East India. 3 Biotech 7: 303.

6. Ibarra JE, Rincón MC, Ordúz S, Noriega D, Benintende G, et al. (2003) Diversity of Bacillus thuringiensis strains from Latin America with insecticidal activity against different mosquito species. Appl Environ Microbiol 69: 5269-5274.

7. Mendoza G, Portillo A, Arias E, Ribas RM, Olmos J (2012) New combinations of CRY genes from Bacillus thuringiensis strains isolated from northwestern Mexico. Int Microbiol 15: 211-218.

8. Corona JEB, Acosta HV, Bideshi KD, Hernández RS (2007) Bacteriocinlike inhibitor substances produced by Mexican strains of Bacillus thuringiensis. Arch Microbiol 187: 117-126.

9. Ramsar W (2007) Information Sheet on Ramsar Wetlands (FIR). Pp. $1-18$.

10. Galván MFL, Carbajal N, Frickey T, Santos L (2009) Microbial identification of the Nichupte-Bojorquez coastal lagoon in Cancun, México. Aquatic Ecology 43: 197-205.

11. Gamboa JRD (2011) Isolation and characterization of Bacillus thuringiensis strains with mosquitocidal activity native of Oaxaca. National Polytech Inst 1: 6-18.

12. DoungLy KC, Gabelli SB (2014) Salting out of proteins using ammonium sulfate precipitation. Method Enzymol 541: 85-94.

13. Salcido NF, Corona JB, Monzón AE, Cano RP, Balagurusamy N, et al. (2012) Expanding the use of fluorogenic method to determine activity and mode of action of Bacillus thuringiensis bacteriocins agains grampositive and gram negative bacteria. Scientific World J 2012: 1-9.

14. Vázquez LEC, Bideshi DK, Corona JEB (2017) The THNR gene in a negative transcription regulator of the thurincin $\mathrm{H}$ genetic cassette in Bacillus thuringiensis. Arch Microbiol 199: 385-390.

15. Xu D, Coté JC (2008) Sequence diversity of Bacillus thuringiensis flagellin ( $\mathrm{H}$ antigen) protein at the intra-H serotype level. Appl Environ Microbiol 74: 5524-5532.

16. Perchat S, Talagas A, Zouhir S, Poncet S, Bouillaut L, et al. (2016) How Quorum sensing connects sporulation to necrotrophism in Bacillus thuringiensis. PloS Pathog 12: 1-21.

17. Salcido NMF, Ramírez JCC, Cruz DL (2016) Bacillus thuringiensis Bacteriocins: Natural antimicrobial promising. Health Sci Magaz 3: 1-10.

18. Marroquín ELS, Wong LJG, Medina VRM, López MAR, Alférez BP (2016) Bacteriocins synthesized by Bacillus thuringiensis: Generalities and potential applications. Rev Med Microbiol 27: 95-101.

19. Lee H, Churey JL, Worobo RW (2009) Biosynthesis and transcriptional analysis of thuricin $\mathrm{H}$, a tandem repeated bacteriocina genetic locus, produced by Bacillus thuringiensis SF361. FEMS Microbiol Lett 299: 205-213.

20. Rea MC, Sit CS, Clayton E, O'Connor PM, Whittal RM, et al. (2010) Thuricin $\mathrm{CD}$, a posttranslationally modified bacteriocin with a narrow spectrum of activity against Clostridium difficile. Proc Natl Acad Sci USA 107: 9352-9357. 
Citation: Lopez de la Cruz D, Valencia-Castro CM, Hernández-Terán F, Barboza-Corona JE, de la Fuente-Salcido NM (2018) Antibacterial Activity of Native Bacillus thuringiensis Strains from Fernandez Canyon State Park, Mexico. J Antimicrob Agents 4: 166. doi: $10.4172 / 2472-1212.1000166$

Page 5 of 5

21. Huang T, Zhang X, Pan J, Su X, Jin X, et al. (2016) Purification and characterization of a novel cold shock protein-like bacteriocin synthesized by Bacillus thuringiensis. Sci Rep 6: 35560 .

22. Xin B, Zheng J, Liu H, Junhua L, Ruan L, et al. (2016) Thusin, a novel two-component lantibiotic with potent antimicrobial activity against several gram-positive pathogens. Front Microbiol 7: 1-12.

23. Favre ME, Yousten AA (1989) Thuricin: The bacteriocin produced by bacillus thuringiensis. J Invertebr Pathol 53: 206-216.

24. Cherif A, Ouzari H, Dffonchio D, Cherif H, Ben SK, et al. (2001) Thuricin 7: A novel bacteriocin produced by Bacillus thuringiensis BMG1.7, a new strain isolated from soil. Lett Appl Microbiol 32: 243-247.
25. Cherif A, Rezgui W, Raddadi N, Daffonchio D, Boudabous A (2008) Characterization and partial purification of entomocin 110, a newly identified bacteriocin from Bacillus thuringiensis subsp. entomocidus HD110. Microbiol Res 163: 684-692.

26. Mathur H, Fallico V, Connor PM, Rea MC, Cotter PD, et al. (2017) Insights into the mode of action of the sactibiotic thuricin CD. Front Microbiol 8: 696. 